\title{
研究速報 論文特集口映像表現とコンピュータグラフィックス〜瞔像表現・芸術科学フォーラム2017を中心に〜
}

\section{スマートフォンとDFD錯視現象を利用した小型3D画像表示装置の 開発}

Development of 3D Display Device Using Smartphone and Depth Fused 3-D (DFD) Phenomenon

三瓶卓方 ${ }^{\dagger}$, 正会員 下馬場朋禄 ${ }^{\dagger}$, 正会員 角江 崇 ${ }^{\dagger}$, 正会員 伊 藤 智 義 ${ }^{\dagger}$

Takuho Sanpei $^{\dagger}$, Tomoyoshi Shimobaba ${ }^{\dagger}$, Takashi Kakue ${ }^{\dagger}$ and Tomoyoshi Ito $^{\dagger}$

あらまし スマートフォンと DFD 錯視現象を利用した小型 $3 \mathrm{D}$ 画像表示装置の開発と DFD 用画像の自動生成システ ムの開発を行った。開発した装置とDFD 用画像を元に複数人の観測者に主観評価を行ってもらった結果, 奥行き知 覚に対して良好な評価を得ることができた。

キーワード：DFD，立体視，スマートフォン

\section{1.まえがき}

近年，3D 映像表示の新たな手法として，DFD（Depth Fused 3-D)錯視現象を利用した表示装置が提案されている1). この手法では, 奥行の異なる位置に 2 枚の画像を配置し, これらの画像の輝度を変化させることで違和感のない奥行 き立体知覚を得られる. 従来の $3 \mathrm{D}$ 映像表示方法と比べ装 置を簡易に構築することが可能であり, 観測者の疲労感も 少ないという利点を持っている．DFDを利用した $3 \mathrm{D}$ 映像 表示の研究は，さまざまなところで行われているが，コン ピュータスクリーンのような大型で高価な光学系を用いて $\mathrm{DFD}$ 錯視を表現しているものが多い.

本研究では, 簡易に構築可能な装置を実現するために, 普及率の高いスマートフォンを用いたDFDによる小型 $3 \mathrm{D}$ 画像表示装置を開発した。 小型の DFD装置の開発事例とし てLCDを 2 枚積層した装置がある2)。この研究では, 特別 に設計されたLCD 用いて完成度の高い装置の開発に成功 している. 本研究では, このような特殊な LCDを用いずに, Google (ardboard ${ }^{3)}$ のコンセプトのような安価な装置を目 指している.また, 本研究ではカメラで撮影した静止画や 動画を3D 表示することを見据え，デプスマップ情報を利 用した DFD 用の前後画像を自動で生成するシステムの構築 を行った。次に構築した装置および自動生成した前後画像 を評価するために, 装置上で前後画像を表示し, 奥行き表 現ができているかどうかの評価を行った。評価方法として, 複数人の観測者の協力を得て, 表示した $3 \mathrm{D}$ 画像について 奥行きを感じるかどうかのアンケートを取った。アンケー 卜結果から, 意図した奥行き表現ができているという結果

2017 年 6 月 9 日受付, 2017 年 7 月 28 日採録

$\dagger$ 千葉大学大学院工学研究科

（テ 263-8522 千葉市稲毛区弥生町 1-33，TEL 043-251-1111)
を得ることができた.

\section{DFDを用いた小型3D画像表示装置}

$\mathrm{DFD}$ 錯視とは, 図1のように奥行き方向前後に2枚の画 像を配置し, 輝度を変化させることで奥行きを表現するこ とができる現象である，例えば，前面の輝度を高く，後面 の輝度を低くすることで，観察者は手前側に映像を知覚す ることができる，逆に前面の輝度を低くし，後面の輝度を 高くすることで，奥側に映像が知覚される1).

装置の概念図を図2に示す。前面画像と後面画像を重敉 るためにハーフミラーとミラーを用い，前後画像を映すた めのディスプレイとして1台のスマートフォンを用いる. 本来，画像を表示するためには，透明なディスプレイが必 要であるが，ハーフミラーとミラーを用いることによって 同等の機能を実現した、スマートフォンのディスプレイに

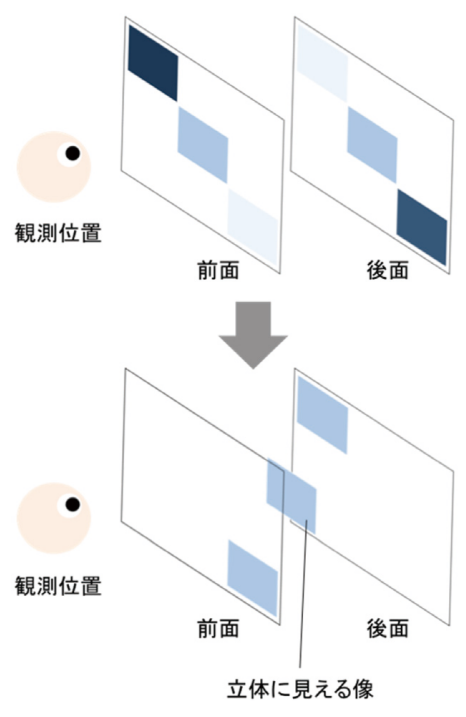

図1 DFD 錯視現象の原理 


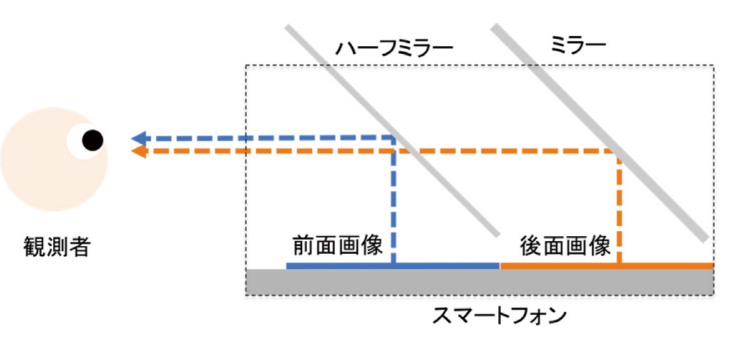

図2 概念図

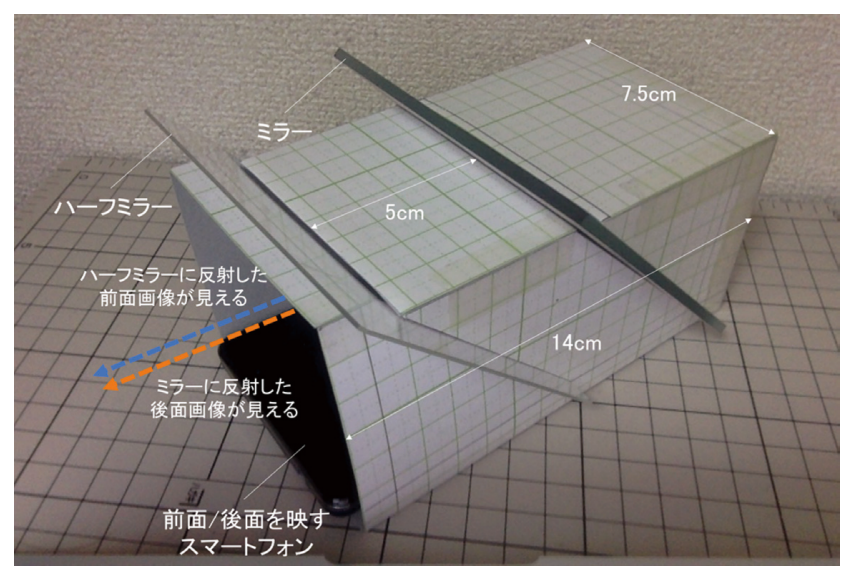

図3 3D画像表示装置

前後画像を表示する。後面画像はミラーに映って反射し， ハーフミラーに映された前面画像と重なることでDFD 錯 視を利用した $3 \mathrm{D}$ 画像を表示する.

図3に実際に開発した3D画像表示装置を示す。ハーフミ ラー，ミラーを設置する筐体は厚紙でできており，この設 計図を例えばインターネットで配布しユーザが印刷するこ とで, Google Cardboard3)のように誰もが簡単にDFD装 置を作成することができる利点がある.

また，前後画像を生成するために Google カメラ4)のデプ スマップ画像を利用する検討を行った. カメラで撮影した 静止画や動画は, 手動で輝度を変化させて前後画像を作成 することが難しいため，デプスマップ情報を元に自動で輝 度を変化させる. Googleカメラは, Googleによって開発さ れたスマートフォン向けのカメラアプリで，スマートフォ ン 1 台だけでデプスマップ情報を含んだレンズぼかし画像 を撮影することができる。このようにディスプレイとして の利用だけでなく．表示画像の撮影にもスマートフォンを 利用した。

\section{3. 奥行き表現の評価}

3D 画像表示装置の評価方法として, 観測者に表示した画 像に対する奥行き表現についてアンケートを取得した。観 測者は, 20 代から 40 代の視力に問題のない男女 13 人で あった。

検証画像は図 4 に示す $\mathrm{A} \sim \mathrm{D}$ である。画像の輝度（前 面：後面）は，A (100\%：25\%), B (75\%：50\%), C (50\%：75\%), D (25\%：100\%)である. 理論的には手前か ら奥に向かって, A $\rightarrow \mathrm{D}$ の順に認識される設定である. 検

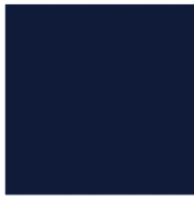

(D)

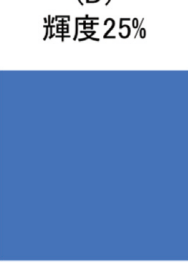

(D)

輝度 $100 \%$

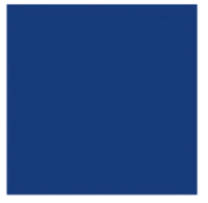

(C) 輝度 $50 \%$

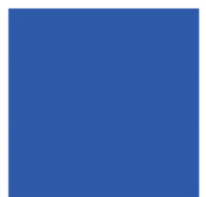

(C)

輝度 $75 \%$

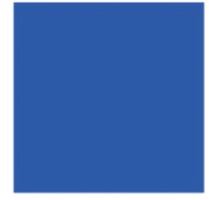

(B) 輝度 $75 \%$

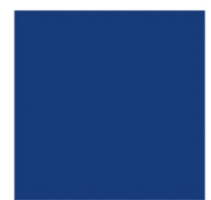

(B)

輝度 $50 \%$

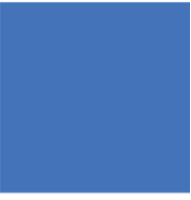

(A) 輝度 $100 \%$

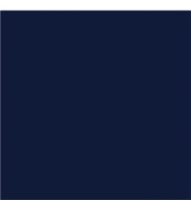

(A)

輝度 $25 \%$
図4 検証画像 (上:前面下:後面)

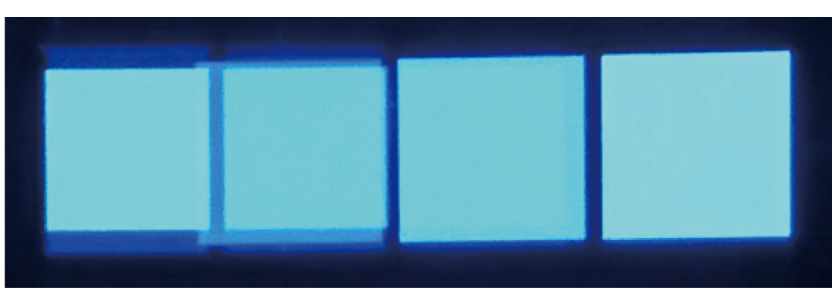

図5 DFD錯視画像

表1 アンケート結果 (\%)

\begin{tabular}{|c|c|c|c|c|}
\hline 前後知覚 & $\mathrm{A}$ & $\mathrm{B}$ & $\mathrm{C}$ & $\mathrm{D}$ \\
\hline 1番 & 92.4 & 7.6 & 0 & 0 \\
\hline 2番 & 7.6 & 92.4 & 0 & 0 \\
\hline 3番 & 0 & 0 & 84.7 & 15.3 \\
\hline 4番 & 0 & 0 & 15.3 & 84.7 \\
\hline
\end{tabular}

証画像を $3 \mathrm{D}$ 画像表示装置上で表示した画像を図5に示す. 装置から観測者までの距離は $100 \mathrm{~cm}$ 程度，前後画像の距離 は $5 \mathrm{~cm}$, 各四角形の大きさは縦横共に $1.4 \mathrm{~cm}$ である. 観測 者には, $\mathrm{A} \sim \mathrm{D}$ の画像に対して，手前に見えたものから 1 $\rightarrow 4$ の順に番号で答えてもらった。

結果を表1に示す.Aが1番目 (一番手前) に見えた割合が $92.4 \% ， B か ゙ 2$ 番目に見えた割合が $92.4 \% ， C か ゙ 3$ 番目に見え た割合が $84.7 \%$ ，Dが4番目に見えた割合が $84.7 \%$ あっった. A と BおよびCとDの順番を逆に答える観測者もいたが，こ のアンケート結果から, 輝度を変化させることにより意図 した順番で奥行きを表現できていることを確認できた。

\section{4.デプスマップを用いたDFD 錯視映像の自動 生成}

続いて, 手動ではなく, カメラで撮影した静止画や動画 を 3D 表示させるために，デプスマップを用いてDFD用の 前後画像を自動生成するシステムの構築を行った。

図6にGoogleカメラで撮影したレンズぼかし画像, 図7 にレンズぼかし画像からデプスマップ情報だけを表示させ た画像を示す．手前に表示されている部分は暗く，奥に表 示されている部分は明るく表示される. 


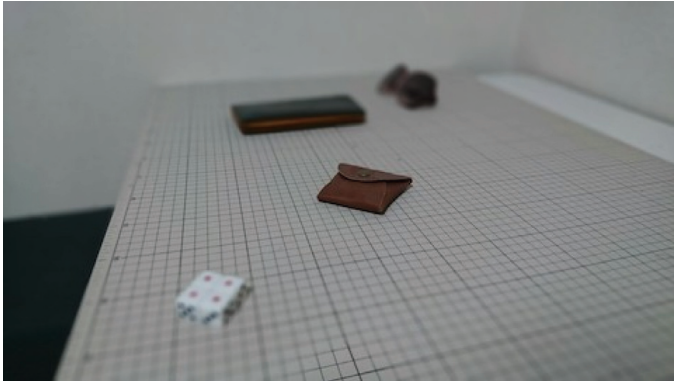

図6 撮影したレンズぼかし画像

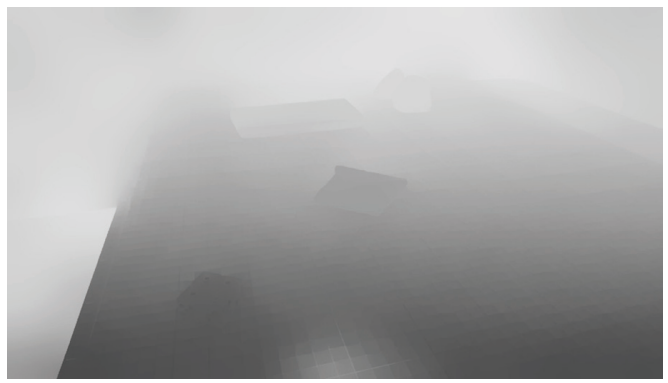

図7 デプスマップ画像
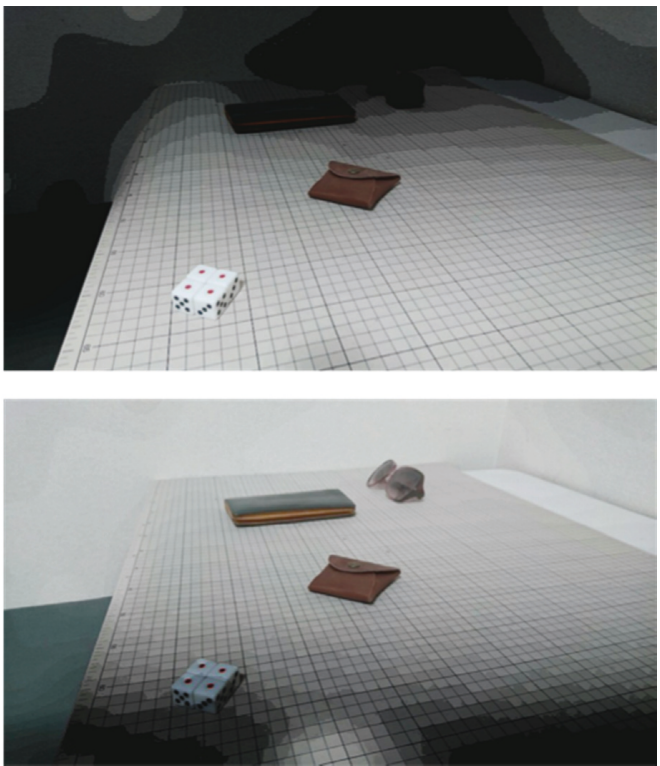

図8 自動作成した前後画像 (上：前面，下：後面）

DFD用画像を自動生成するために，デプスマップ画像か ら画素ごとの輝度を取得する. 取得した輝度を20のレンジ に分け，輝度レベル毎に画像処理を行った。具体的には， 輝度が高い部分は前面画像を明るく，後面画像は暗く，輝 度值が低い部分はそれぞれ逆の処理を行う. 図8に自動作 成を行った前後画像を示す。

観測者に図 9 の前後画像を装置上に表示した図 9 の DFD 錯視画像を見てもらい，奥行きを感じるかどうかの質問を 行った。装置から観測者までの距離および前後画像の距離 は同じで，画像の大きさは縦 $3.5 \mathrm{~cm}$, 横 $6.2 \mathrm{~cm}$, デプス マップ画像の奥行き範囲は $100 \mathrm{~cm}$ である.

結果としては， 13 人中 13 人の観測者から奥行きを感じる という回答を得た。ただし, 前後画像で輝度の差がない画

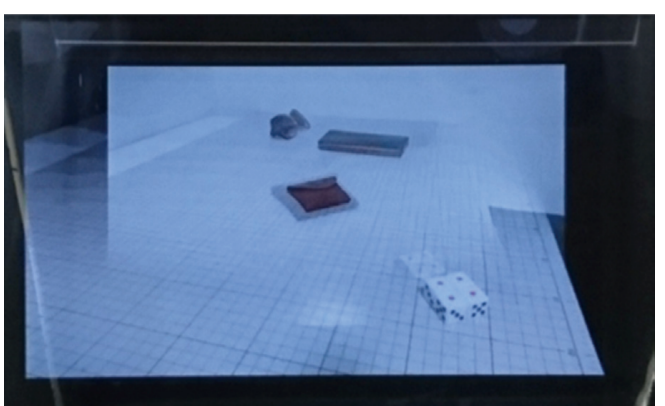

図9 DFD 錯視画像

像中央部分に関しては，像が重ならず見にくいという指摘 があった。これは，輝度の差が少ないため画像を重ねた際 に，前後画像ともその部分がはっきりと見えてしまい，目 の焦点が合わないことが原因だと推測される.

\section{5.むすび}

スマートフォンを用いた3D 画像表示装置の開発および DFD用画像の自動生成システムの構築を行った。構築した 装置上で評価を用い，奥行きを表現することができた。今 後の課題として，前後画像の輝度の差が少ない部分につい ての処理，および，デプスマップ情報がついた動画の撮影 についての検討を行う.

\section{〔文 献〕}

1) S. Suyama, S. Ohtsuka, H. Takada, K. Uehira and S. Sakai: "Apparent 3-D Image Perceived from Luminance-Modulated Two 2-D Images Displayed at Different Depths", Vision Research, 44, 785-793 (2004)

2）高田英明，陶山史朗，伊達宗和，昼間香織，中沢憲二：“前後 2 面の LCD を積層した小型DFD ディスプレイ”，映情学誌，58，6，pp.807$810(2004)$

3) https://vr.google.com/intl/ja_jp/cardboard/

4) https://support.google.com/googlecamera/?hl=ja

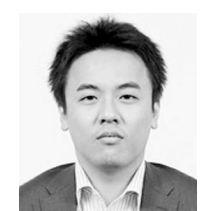

总瓶卓告 2010 年，山形大学大学院理工学研究科 博士前期課程修了. 現在, 千葉大学大学院工学研究科博 士後期課程在学中. 3 次元映像技術や教材開発の研究に従 事. WEBエンジニア.

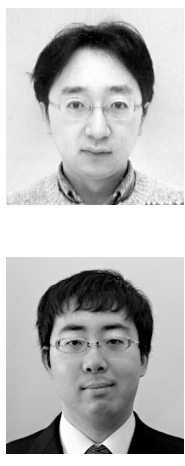

卡暂場苝禄 2002 年, 千葉大学大学院自然科学研究 科博士課程修了. 同年, 理化学研究所基礎科学特別研究 員. 2005 年, 山形大学工学部助教授. 2007 年, 同大学院 理工学研究科准教授. 2009年, 千葉大学工学研究科准教 授。ホログラフィ応用技術の研究に従事. 博士 (工学). 正会員.

角江染 2008 年, 京都工芸瀻維大学大学院工芸 科学研究科電子システム工学専攻修了. 2011 年, 日本学 術振興会特別研究員 (DC2). 2012 年, 京都工芸瀻維大学 大学院工芸科学研究科設計工学専攻修了。同年, 千葉大 学大学院工学研究科助教. ホログラフイに基づく 3 次元 映像技術や 3 次元計測技術に従事. 博士 (工学). 正会員.

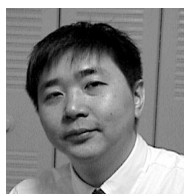

伊藤 智義 1992 年, 東京大学大学院総合文化研究 科博士課程中退. 同年, 群馬大学工学部助手。1994年, 同大学助授. 1999年, 千葉大学工学部助教授. 2004年, 同大学教授. 専用計算機による数值計算の高速化の研究 に従事. 博士 (学術). 正会員. 